\title{
Pelatihan Perumusan Analisis SWOT bagi Dosen dan Pemangku Kepentingan di Bidang Rekam Medis
}

\author{
Ressa Oashttamadea* \\ Program Studi DIII Ilmu Rekam Medis, Apikes Iris, Padang, Indonesia \\ *oashttamadea@yahoo.com
}

\begin{abstract}
ABSTRAK
Analisis SWOT (Strength, Weakness, Opportunity, Threat) adalah perangkat yang membantu manajer sebuah organisasi untuk mengevaluasi kekuatan, kelemahan, peluang dan ancaman yang terlibat dalam perusahaan. Fasilitas pelayanan kesehatan merupakan salah satu institusi yang berkembang pesat, dan pelayanan rekam medis merupakan salah satu pelayanan penunjang yang menjadi dasar penilaian mutu pelayanan medik rumah sakit. Institusi kesehatan seperti rumah sakit beserta lembaga pendidikan di bidang rekam medis harus bisa menetapkan metode SWOT sebagai landasan dasar perumusan strategi pemasaran untuk meningkatkan nilai daya saing. Metode pengabdian kepada masyarakat ini adalah pendidikan masyarakat dalam bentuk webinar melalui aplikasi Zoom. Pelatihan ini dilaksanakan pada tanggal 13 Juni 2020 dengan peserta berjumlah 27 orang, yang dilakukan dalam bentuk presentasi, tanya jawab, latihan soal dan diskusi. Topik yang dibahas mencakup: dasar analisis SWOT, tahap identifikasi SWOT, pembobotan dan skor, perumusan grafik dan grand matrix strategy terkait pengembangan rekam medis. Sebelum pelatihan dilakukan, peserta hanya mampu melakukan analisis SWOT hingga tahap identifikasi, dan setelah diberikan pelatihan peserta mampu melakukan analisis hingga tahap perumusan grand matrix strategy. Kesimpulan pelatihan ini adalah pelatihan bermanfaat bagi dosen dan pemangku kepentingan di bidang rekam medis dan manajemen informasi kesehatan dalam merumuskan analisis SWOT.
\end{abstract}

Kata Kunci: Analisis SWOT, Manajemen, Rekam Medis

Received: July 28, 2020

Revised: August 20, 2020

Accepted: August 30, 2020

This is an open-acces article distributed under the terms of the Creative Commons Attribution-ShareAlike 4.0 International License.

\section{PENDAHULUAN}

Pengembangan organisasi didefinisikan beragam oleh praktisi dan ahli teori, salah satunya karena kompleksitasnya. Pada dasarnya, pengembangan organisasi adalah upaya terencana yang dilakukan di tingkat organisasi untuk meningkatkan efektivitas dan/atau memungkinkan organisasi untuk mencapai sasaran strategisnya. Konsep ini secara resmi muncul pada 1950-an (meskipun beberapa teori mundur ke tahun 1920) dan umumnya merujuk kepada psikolog Kurt Lewin. Pengembangan organisasi mencakup teori dan praktik dari perubahan terencana dan sistemik pada sikap, keyakinan, dan perilaku pegawai melalui program pelatihan jangka panjang. Hal ini sering kali digambarkan sebagai "berorientasi pada tindakan". Biasanya, pengembangan ini dimulai dengan mendiagnosis status quo dan kebutuhan di tingkat organisasi secara saksama. Bidang-bidang terkait yang 
muncul meliputi pengembangan kapasitas, pemikiran sistem, pemikiran kompleksitas, epidemiologi klinis, dan pembelajaran organisasi (Mackenzie, 2016).

Saat ini sebagian besar organisasi terlibat dalam perencanaan strategis. Perencanaan strategis adalah cara untuk membantu sebuah organisasi menjadi lebih produktif dengan membantu mengarahkan alokasi sumber daya untuk mencapai tujuan. Manajemen strategis memungkinkan organisasi untuk menjadi lebih proaktif daripada reaktif dalam membentuk masa depannya sendiri. Manajemen strategis terdiri dari analisis, keputusan, dan tindakan yang dilakukan organisasi untuk menciptakan dan mempertahankan keunggulan kompetitif. Proses manajemen strategis adalah serangkaian analisis dan pilihan yang dapat meningkatkan kemungkinan bahwa suatu organisasi akan memilih 'strategi yang baik', yaitu yang menghasilkan keunggulan kompetitif (Gurel, 2017).

Berdasarkan panduan dari United Nations, metode yang umum dan mudah digunakan untuk menganalisis kondisi sebuah organisasi adalah analisis SWOT. SWOT merupakan singkatan dari Strength (kekuatan), Weakness (kelemahan), Opportunity (kesempatan), dan Threat (ancaman). Sebuah analisis SWOT dapat memberikan kesimpulan atau gambaran mengenai persepsi organisasi, misalnya kepemimpinan atau kondisi karyawan. Menurut Ommani (2011), analisis SWOT (Strength, Weakness, Opportunity, Threat) adalah perangkat yang membantu manajer sebuah organisasi untuk mengevaluasi kekuatan, kelemahan, peluang dan ancaman yang terlibat dalam perusahaan. Analisis SWOT dapat membantu mereka mendapatkan wawasan ke masa lalu dan memikirkan solusi yang mungkin untuk masalah yang ada atau berpotensial untuk muncul. Analisis SWOT menentukan apa yang dapat membantu perusahaan mencapai tujuannya, dan apa hambatannya dapat diatasi atau diminimalkan untuk mencapai hasil yang diinginkan.

Fasilitas pelayanan kesehatan merupakan salah satu institusi yang berkembang pesat dari segi kualitas dan kuantitas sehingga membutuhkan strategi untuk meningkatkan daya saing. Pelayanan rekam medis merupakan salah satu pelayanan penunjang medis di rumah sakit yang menjadi dasar penilaian mutu pelayanan medik rumah sakit. Rekam medis pasien berisi informasi tentang catatan dan dokumen tentang identitas pasien, pemeriksaan, pengobatan, tindakan dan pelayanan lain yang telah diberikan kepada pasien (Depkes, 2006). Permenkes Nomor 377 Tahun 2007 tentang Kompetensi Perekam Medis menjelaskan bahwa terselenggaranya manajemen informasi kesehatan dimulai dari dibuatnya rekam medis secara baik dan benar oleh tenaga kesehatan di sarana pelayanan kesehatan. Rekam medis kemudian dikelola secara terencana melalui teknologi informasi dan komunikasi yang berkelanjutan.

Menurut Ngo, dkk (2016), upaya terkini untuk meningkatkan pelayanan terhadap pasien kesehatan pasien meliputi terobosan ilmiah, inovasi medis dan kemajuan teknologi. Rekam medis dalam hal ini menempati kategori terakhir; dimana rekam medis merupakan sebuah portal bagi staf medis untuk mengetahui sejarah pasien terkait perawatan medis terhadulu, memahami diagnosis dan penatalaksanaan pada pasien, dan menggunakan informasi yang ada untuk evaluasi di masa yang akan datang. Dalam hal pengembangan rekam medis, tidak hanya pihak rumah sakit yang melakukan kontribusi, namun juga institusi pendidikan. Pendidikan merupakan salah satu jaminan untuk memperoleh kehidupan yang lebih baik sekaligus kemartabatan yang tinggi baik secara material maupun transcendental. Melalui pemahaman inilah, pendidikan secara otomatis menempati posisi yang sangat sentral dan strategis dalam membangun kehidupan manusia ke depan yang berkualitas dan seimbang. Untuk meningkatkan kualitas lembaga pendidikan, pengelolaan pendidikan harus dikelola dan disentuh secara professional dan 


\section{Journal of Community Engagement in Health}

http://jceh.org

ISSN: 2620-3758 (print); 2620-3766 (online)

https://doi.org/10.30994/jceh.v3i2.69

Vol.3 No.2. Sep 2020. Page.239-245

fungsional sesuai tuntutan dunia kemanajemenan, artinya berbagai sumber daya yang mempengaruhi terjadinya seluruh proses pendidikan perlu ditangani secara terencana, terorganisir, terarah dan terkendali. Dari konteks inilah maka lembaga pendidikan dituntut memiliki kompetensi manajerial yakni kemampuan membangun pola kerja yang sistematis, logis, realistis dan strategis (Mappasiara, 2018).

Pemerintah Indonesia dalam upaya meningkatkan pendidikan, tidak henti-hentinya melakukan berbagai kegiatan dan menyediakan fasilitas pendukung termasuk memberlakukannya Undang-Undang Nomor 14 tahun 2005 tentang guru dan dosen (Nurmasyitah, 2016). Selain itu, untuk menghadapi persaingan pasar, terutama dalam menghadapi pasar global, institusi kesehatan seperti rumah sakit beserta lembaga pendidikan harus bisa menetapkan metode SWOT sebagai landasan dasar perumusan strategi pemasaran untuk meningkatkan nilai daya saing bagi produknya, strategi ini perlu dilibatkan dengan menggunakan metode SWOT sebagai metode utama guna meningkatkan penjualan, faktor-faktor internal dan eksternal menjadi langkah-langkah awal untuk melakukan strategi-strategi guna mengoptimalkan usaha untuk meraih kesuksesan (Elyarni, 2016). Berdasarkan latar belakang di atas, maka penting untuk tenaga pendidik dan pemangku kepentingan di bidang rekam medis untuk memahami manajemen strategis terkait dengan analisis SWOT.

\section{BAHAN DAN METODE}

Kegiatan pengabdian kepada masyarakat ini diadakan pada masa pandemi Covid-19 sehingga pelaksanaannya dilakukan melalui webinar dengan menggunakan aplikasi Zoom. Kegiatan ini dilaksanakan melalui 3 (tiga) tahap, yaitu:

1. Tahap Perencanaan

Tahap ini terdiri dari persiapan tim untuk sosialisasi penggunaan aplikasi, penyebaran flyer melalui media sosial, dan pendaftaran peserta melalui google form. Pada saat peserta melakukan pendaftaran, peserta diminta mengisi kuesioner untuk mengevaluasi tingkat pemahaman peserta mengenai analisis SWOT.

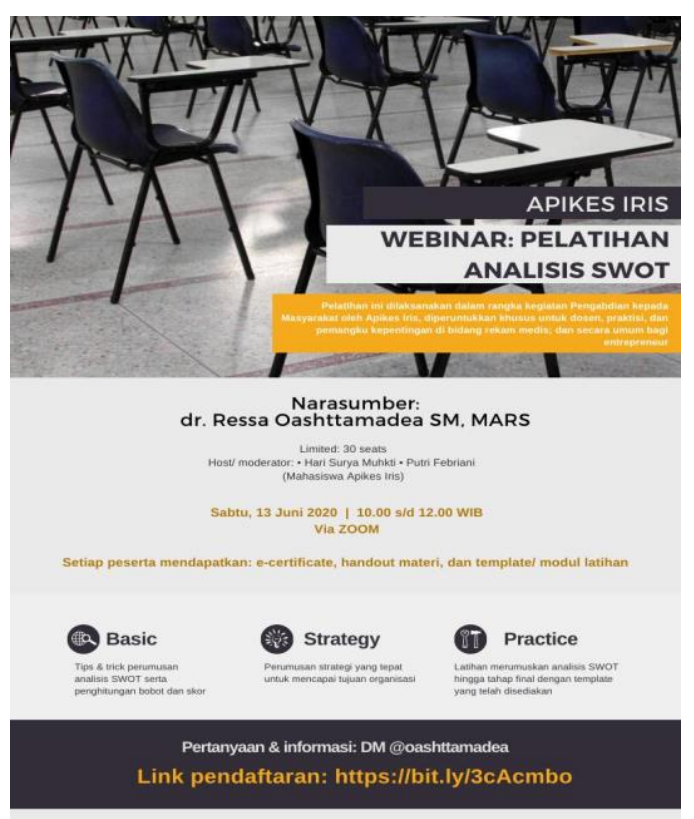

Gambar 1. Flyer Pendaftaran 


\section{Journal of Community Engagement in Health}

http://jceh.org

ISSN: 2620-3758 (print); 2620-3766 (online)

https://doi.org/10.30994/jceh.v3i2.69

Vol.3 No.2. Sep 2020. Page.239-245

2. Tahap Pelaksanaan

Webinar ini dilaksanakan pada tanggal 13 Juni 2020 melalui aplikasi Zoom. Pendanaan kegiatan ini bersumber dari Hibah LPPM Apikes Iris Tahun 2020. Metode pelaksanaan PKM ini adalah presentasi, tanya jawab, latihan mengisi template analisis SWOT yang telah disediakan pengabdi, dan bedah kasus. Materi yang diberikan kepada peserta adalah sebagai berikut:

- Dasar-dasar analisis SWOT

- Tahap melakukan identifikasi SWOT

- Metode pembobotan dan skor

- Grafik SWOT

- Grand matrix strategy

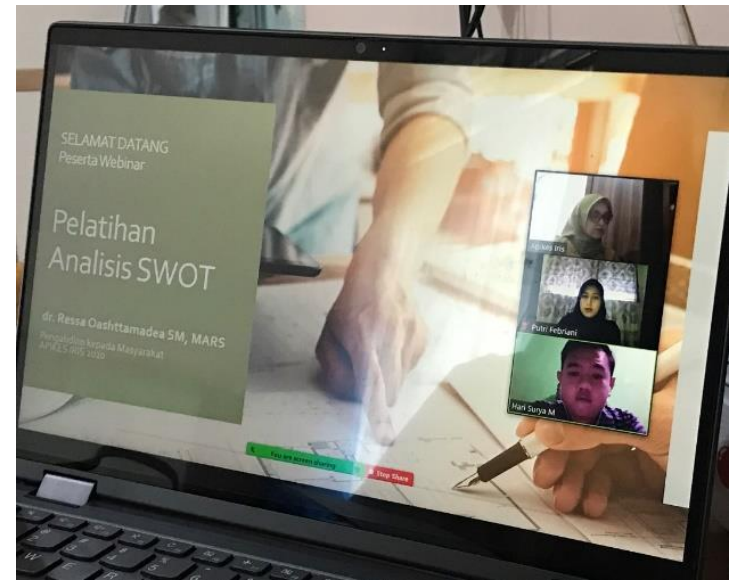

Gambar 2. Tim Pengabdi

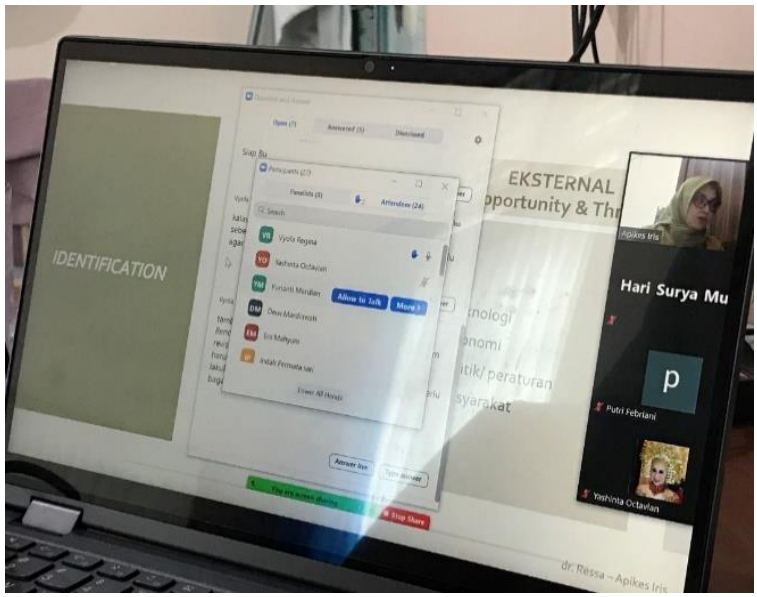

Gambar 3. Kegiatan Webinar

3. Tahap Evaluasi

Setelah webinar ini dilaksanakan, setiap peserta mendapatkan template analisis SWOT yang dibuat oleh tim pengabdi agar dapat dijadikan pedoman Latihan bagi peserta. Selanjutnya, peserta kembali diberikan kuesioner untuk melihat hasil dari pelatihan yang dilakukan. 


\section{Journal of Community Engagement in Health}

\section{HASIL}

Pengabdian kepada masyarakat (PKM) ini dilaksanakan pada tanggal 13 Juni 2020 melalui aplikasi Zoom. Peserta PKM ini berjumlah 27 orang, yang berasal dari institusi pendidikan seperti dosen di bidang rekam medis, serta praktisi rumah sakit yang bekerja di bagian rekam medis atau mengepalai bagian rekam medis. Saat melalukan pendaftaran, peserta diminta untuk mengisi kuesioner mengenai pemahaman peserta terhadap analisis SWOT. Berdasarkan pretest, berikut tingkat pemahaman peserta dalam melakukan analisis SWOT:

Tabel 1. Gambaran Pemahaman Peserta dalam Melakukan Analisis SWOT (Pretest)

\begin{tabular}{|c|c|c|}
\hline Materi & $\begin{array}{c}\text { Jumlah Peserta } \\
\text { yang Menguasai } \\
\text { Materi }\end{array}$ & Persentase \\
\hline $\begin{array}{l}\text { Definisi dan dasar analisis } \\
\text { SWOT }\end{array}$ & 27 peserta & $100 \%$ \\
\hline Identifikasi SWOT & 25 peserta & $92 \%$ \\
\hline Pembobotan dan skor & 5 peserta & $18,5 \%$ \\
\hline Grafik SWOT & 0 peserta & $0 \%$ \\
\hline Grand matrix strategy & 0 peserta & $0 \%$ \\
\hline
\end{tabular}

Setelah PKM dilaksanakan, peserta mengisis posttest untuk melihat tingkat pemahaman terkait materi yang telah diberikan yang dsajikan pada Tabel 2:

Tabel 2. Gambaran Pemahaman Peserta dalam Melakukan Analisis SWOT (Posttest)

\begin{tabular}{|l|l|c|}
\hline \multicolumn{1}{|c|}{ Materi } & $\begin{array}{c}\text { Jumlah Peserta } \\
\text { yang Menguasai } \\
\text { Materi }\end{array}$ & Persentase \\
\hline $\begin{array}{l}\text { Definisi dan dasar analisis } \\
\text { SWOT }\end{array}$ & 27 peserta & $100 \%$ \\
\hline Identifikasi SWOT & 27 peserta & $100 \%$ \\
\hline Pembobotan dan skor & 27 peserta & $100 \%$ \\
\hline Grafik SWOT & 27 peserta & $100 \%$ \\
\hline Grand matrix strategy & 27 peserta & $100 \%$ \\
\hline
\end{tabular}

Selain itu, peserta juga mengisi kuesioner mengenai umpan balik setelah mengikuti webinar ini. Berikut hasil dari kuesioner yang telah dilakukan:

1. Tingkat kepuasan peserta mengikuti webinar:

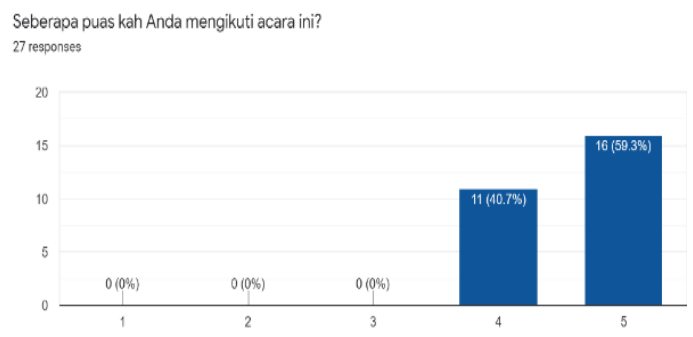


2. Relevansi topik webinar dengan pekerjaan peserta:

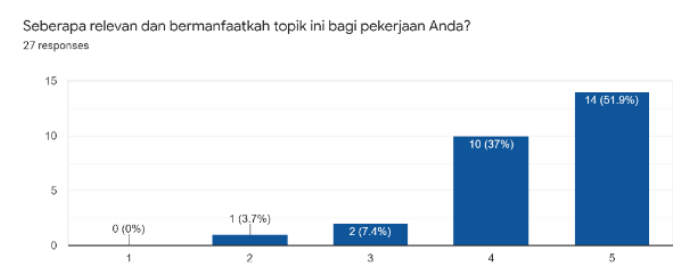

3. Pendapat peserta mengenai pelaksanaan webinar:

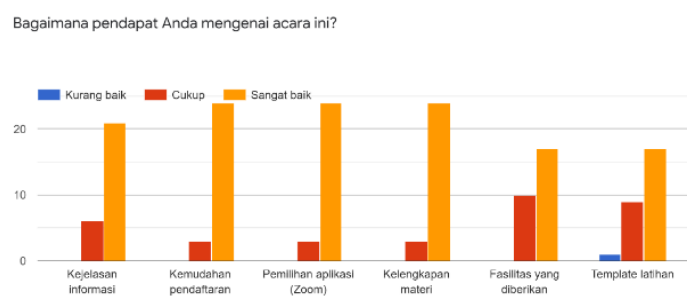

4. Materi yang paling bermanfaat bagi peserta:

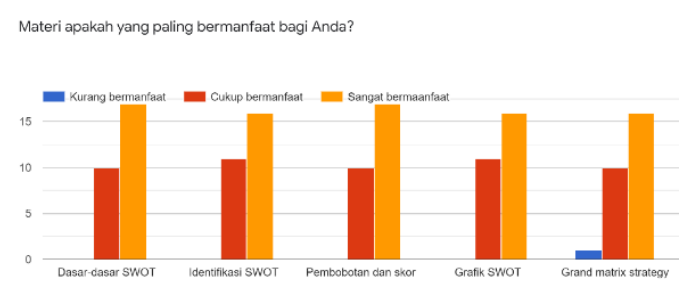

\section{PEMBAHASAN}

Pada kegiatan pengabdian kepada masyarakat ini, pada hasil pretest dapat dilihat bahwa secara garis besar peserta hanya memahami analisis SWOT hingga langkah identifikasi kondisi internal dan eksternal, sedangkan tidak ada peserta yang menguasai materi hingga perumusan grand matrix stratregy. Setelah diadakannya pelatihan ini, seluruh peserta dapat memahami analisis SWOT hingga langkah perumusan grand matrix strategy yang dibutuhkan bagi pengembangan di bagian rekam medis sebuah rumah sakit.

\section{KESIMPULAN}

Pelatihan perumusan analisis SWOT bermanfaat bagi dosen dan pemangku kepentingan, terutama di bidang rekam medis dan manajemen informasi kesehatan, dalam mengalisis posisi organisasi dan melakukan perumusan strategi bagi pengembangan rekam medis. Ke depannya diharapkan kegiatan ini dapat dilanjutkan dengan memberikan materi lanjutan mengenai perumusan manajemen strategik di bidang rekam medis sehingga peserta menerima pelatihan yang berkesinambungan.

\section{REFERENSI}

Departemen Kesehatan RI. 2006. Pedoman Penyelenggaraan dan Prosedur Rekam Medis Rumah Sakit di Indonesia Revisi II, Jakarta: Direktorat Jenderal Bina Pelayanan Medik.

Elyarni, R., Hermanto. 2016. Analisis SWOT terhadap strategi pemasaran layanan sap express pada pt. Sap. Jakarta: Jurnal Metris. 
Gurel, E., Tat, M. 2017. SWOT analysis: Theoritical review. Turki: The Journal of International Social Research.

Mackenzie, J., Gordon, R. 2016. Studi pengembangan organisasi. Jakarta: Kementerian PPN/ Bappenas.

Mappasiara. 2018. Manajemen strategik dan manajemen operasional serta implementasinya pada lembaga pendidikan. Gowa: Jurnal Manajemen Pendidikan Idaarah.

Menteri Kesehatan Republik Indonesia, 2007. Peraturan Menteri Kesehatan Republik Indonesia Nomor 377 Tahun 2007 tentang Kompetensi Perekam Medis.

Ngo, E., dkk. 2016. The importance of the medical record: A critical professional responsibility. Greenbranch Publishing: Journal of Medical Practice Management.

Nurmasyitah, Murniati, Nasir, U. 2015. Implementasi manajemen stratejik dalam meningkatkan kinerja guru pada sekolah menengah kejuruan negeri 3 lhokseumawe. Universitas Syiah Kuala: Jurnal Administrasi Pendidikan.

Ommani, A. R. 2011. Strengths, weaknesses, opportunities and threats (SWOT) analysis for farming system businesses management: case of wheat farmers of shadervan district, shoushtar township, iran. Afrika: African Journal of Bussiness Management.

United Nation. Strategic Planning Guide for Managers. Diakses pada tanggal 20 Mei 2020 dari

https://hr.un.org/sites/hr.un.org/files/4.5.1.6_Strategic\%20Planning\%20Guide_0.pdf. 